Stratigraphy of the

Bois Blanc Formation

in New York

GEOLOGIGAL SURVEY PROFESIONAL PAPER 584-A 



\section{Stratigraphy of the}

Bois Blanc Formation

\section{in New York}

By WILLIAM A. OLIVER, JR.

STRATIGRAPHY AND PALEONTOLOGY OF THE BOIS BLANC FORMATION IN NEW YORK

GEOLOGICAL SURVEY PROFESIONAL PAPER $584-A$

Description of a little-known limestone

formation of Early Devonian age

in western New York

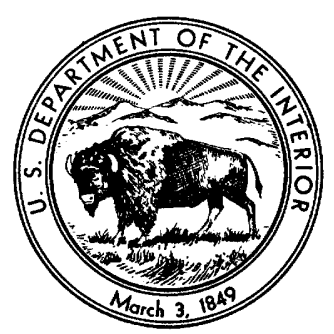

UNITED STATES GOVERNMENT PRINTING OFFICE, WASHINGTON : 1967 


\section{UNITED STATES DEPARTMENT OF THE INTERIOR \\ STEWART L. UDALL, Secretary \\ GEOLOGICAL SURVEY \\ William T. Pecora, Director}

For sale by the Superintendent of Documents, U.S. Government Printing Office

Washington, D.C. 20402 - Price 45 cents (paper cover) 


\section{CONTENTS}

Abstract.
Introduction
Previous work.
$\quad$ Schoharie Formation
Bois Blanc Formation

\section{ILLUSTRATIONS}

Plate 1. Map showing Bois Blanc outcrops in western New York and the Niagara Peninsula of Ontario

Page

FIgURE 1. Correlation of the Bois Blane and Onondaga Formations of western New York with formations in southwestern

Ontario and eastern New York

2. Index map showing areas and localities in Michigan, southwestern Ontario, and New York

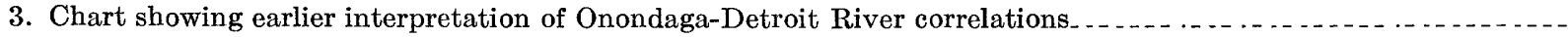

4. Columnar section of Bois Blanc and Onondaga Formations near Buffalo, N.Y.

5. Columnar sections showing lithic sequences at base of Bois Blanc and Onondaga Formations 


\title{
STRATIGRAPHY AND PALEONTOLOGY OF THE BOIS BLANC FORMATION IN NEW YORK
}

\section{STRATIGRAPHY OF THE BOIS BLANG FORMATION IN NEW YORK}

\author{
By Wilutam A. Outvar, Jr.
}

\begin{abstract}
The Bois Blanc Formation, thickest and most widespread in the Michigan Basin, extends eastward to western New York where it is thin and discontinuous beneath the Onondaga Limestone.

Historically, Bois Blanc rocks have been included in the Onondaga Limestone or have not been recognized in Ontario and New York. Recent studies show the Bois Blanc to be Schoharie (late Early Devonian) in age and to be separated from the overlying Onondaga Limestone and Detroit River Group by a disconformity that is probably widespread.

The Bois Blanc and Schoharie Formations contain brachiopods and corals that are distinctly different from underlying and overlying faunas. The Schoharie-Bois Blanc fauna is widespread in a province that covers most of eastern North America.
\end{abstract}

\section{INTRODUCTION}

The lower boundary of the Onondaga Limestone is clearly defined in central and eastern New York (fig. 1) where the Edgecliff Member either disconformably overlies Oriskany or older rocks or rests on the Schoharie Formation of distinctly different lithology. In the Niagara Peninsula of southwestern Ontario, and locally in western New York, the Edgecliff Member is underlain by older limestone that has commonly been included in the Onondaga. The subEdgecliff limestone in these areas is lithologically distinct and is separated from the Edgecliff by a disconformity.

Farther west, in the Michigan Basin, limestones similar to those underlying the Edgecliff underlie the Detroit River Formation or Group and are termed the Bois Blanc Formation. The subEdgecliff limestone is laterally continuous with the Bois Blanc and should be included in that formation.

The Schoharie-Bois Blanc and Onondaga-Detroit River intervals contain distinct faunas that have long been accepted as useful time-rock indices, recognizable over the eastern half of North America. In literature these have been referred to as "lower" and "upper Onondaga," or "Schoharie" and "Onondaga," respectively. Because "lower Onondaga" has never included any part of the Onondaga Limestone in its type area, this usage is misleading. The Schoharie and Onondaga Formations are clearly defined rock units. Their type sections in central and eastern New York define two informal time-rock units. These two units with a third, lower unit form the Onesquethaw Stage in the standard New York section (fig. 1). Present evidence indicates that the Lower-Middle Devonian boundary is between the Schoharie and Onondaga.

The purpose of this paper is to describe the Bois Blanc Formation of Schoharie age in western New York and adjacent Ontario where it underlies the Onondaga Limestone. A historical review of both Schoharie and Bois Blanc usage precedes the description of the Bois Blanc.

\section{PREVIOUS WORK}

\section{SCHOHARIE FORMATION}

The Schoharie Formation and Onondaga Limestone have been recognized as distinct lithologic units since the early New York surveys. Early workers, perhaps uncritically, accepted them as successive units, the Onondaga overlying the Schoharie.

Detailed restudy of the Schoharie began with several areal reports of the New York State Museum (Ruedemann, 1930, p. 60-61; Goldring, 1931, p. 384; 1935, p. $136 ; 1943$, p. 212) and culminated with a redescription and analysis of the whole formation by Goldring and Flower (1942). In the works cited, Ruedemann and Goldring described the Schoharie-Onondaga contact as lithologically gradational and suggested that the Schoharie was a basal sandy facies of the Onondaga, although it is not clear whether they meant that the Schoharie Formation was the time equivalent of a part of the Onondaga farther west or merely that deposition was continuous from one to the other. Goldring and Flower (1942, p. 691) noted that the gradation could be due to the reworking of Schoharie clastics into the initial Onondaga deposit.

Chadwick (1944, p. 93, 153) provided a dissenting voice in the Schoharie-Onondaga relationship question. 


\begin{tabular}{|c|c|c|c|c|}
\hline $\begin{array}{l}\text { London-Woodstock } \\
\text { area, Ontario }\end{array}$ & $\begin{array}{c}\text { Buffalo area, } \\
\text { Ontario-New York }\end{array}$ & $\begin{array}{l}\text { Helderberg area, } \\
\text { eastern New York }\end{array}$ & $\begin{array}{l}\text { New York } \\
\text { stages }\end{array}$ & Series \\
\hline Delaware Limestone & Hamilton Group & Hamilton Group & Cazenovia & \\
\hline $\begin{array}{l}\text { “Columbus" Limestone } \\
\text { Detroit River Group }\end{array}$ & Onondaga Limestone & Onondaga Limestone & \multirow{5}{*}{ Onesquethaw } & Middle Devonian \\
\hline \multirow{2}{*}{ 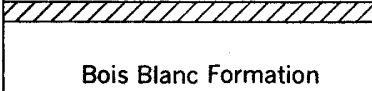 } & 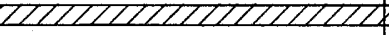 & 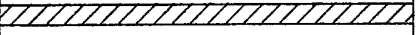 & & \multirow{7}{*}{ Lower Devonian } \\
\hline & Bois Blanc Formation & Schoharie Formation & & \\
\hline \multirow{5}{*}{ 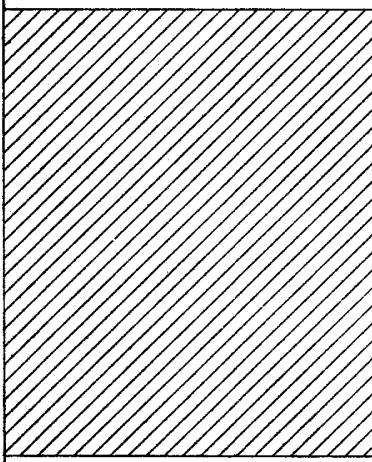 } & \multirow{5}{*}{ W } & Carlisle Center Formation & & \\
\hline & & Esopus Shale & & \\
\hline & & Oriskany Sandstone & Deerpark & \\
\hline & & Helderberg Group & Helderberg & \\
\hline & & Rondout Limestone & \multirow{2}{*}{ Cayuga } & \\
\hline Akron and Bertie Formations & Akron and Bertie Formations & Cobleskill Limestone & & Upper Silurian \\
\hline
\end{tabular}

Frgure 1.-Correlation of the Bois Blanc and Onondaga Formations of western New York with formations in southwestern Ontario and eastern New York.

He described a glauconite bed separating the two formations locally and considered this to indicate an unconformity.

The interpretation of the Schoharie as a clastic facies of the Onondaga was clearly stated at least as far back as 1902 (Clarke, 1902, p. 667-668) but was given renewed emphasis by the works of Ruedemann, Goldring, and Goldring and Flower cited above. This work and faunal studies discussed below certainly influenced Cooper and others (1942, p. 1748, 1756, 1774, 1779-1780) to refer to the Schoharie and equivalent formations as "lower Onondaga." On their correlation chart, these authors clearly indicated the Schoharie Formation to be the time equivalent of the lower part of the Onondaga Limestone in New York areas west of the known limits of the Schoharie.

Oliver $(1954,1956)$ redescribed the Onondaga Limestone in eastern New York and accepted the Schoharie as a facies of the lowest part of the formation. Later, however, he suggested that the lowest member of the Onondaga was time parallel and everywhere younger than units containing the Schoharie fauna (Oliver, 1960, 1963). Johnsen and Southard (1962) came to the same conclusion in the most recently published study of the
Schoharie, and the recent New York Devonian correlation chart (Rickard, 1964) followed this interpretation.

\section{BOIS BLANC FORMATION}

The Bois Blanc Formation, as here recognized, extends from the Michigan Basin to western New York across southwestern Ontario (fig. 2). The Findlay arch (Eardley, 1951, p. 36-37, fig. 1, p. 29) roughly bisects southwestern Ontario and serves as a convenient dividing line between Michigan Basin and New York sequences. West of the arch, the Bois Blanc is overlain by the Detroit River Formation or Group; east of the arch, it is overlain by the Onondaga Limestone in the Niagara Peninsula of Ontario and in western New York. The Bois Blanc is best developed within the Michigan Basin and only the thin eastern part of the formation extends over the arch to New York.

Stauffer (1915) described the Devonian limestone sequence in southwestern Ontario. For the Niagara Peninsula he gave the following generalized section (in descending order) :

5. Very cherty gray limestone with meager fauna.

4. Cherty, bluish black compact limestone with corals. 


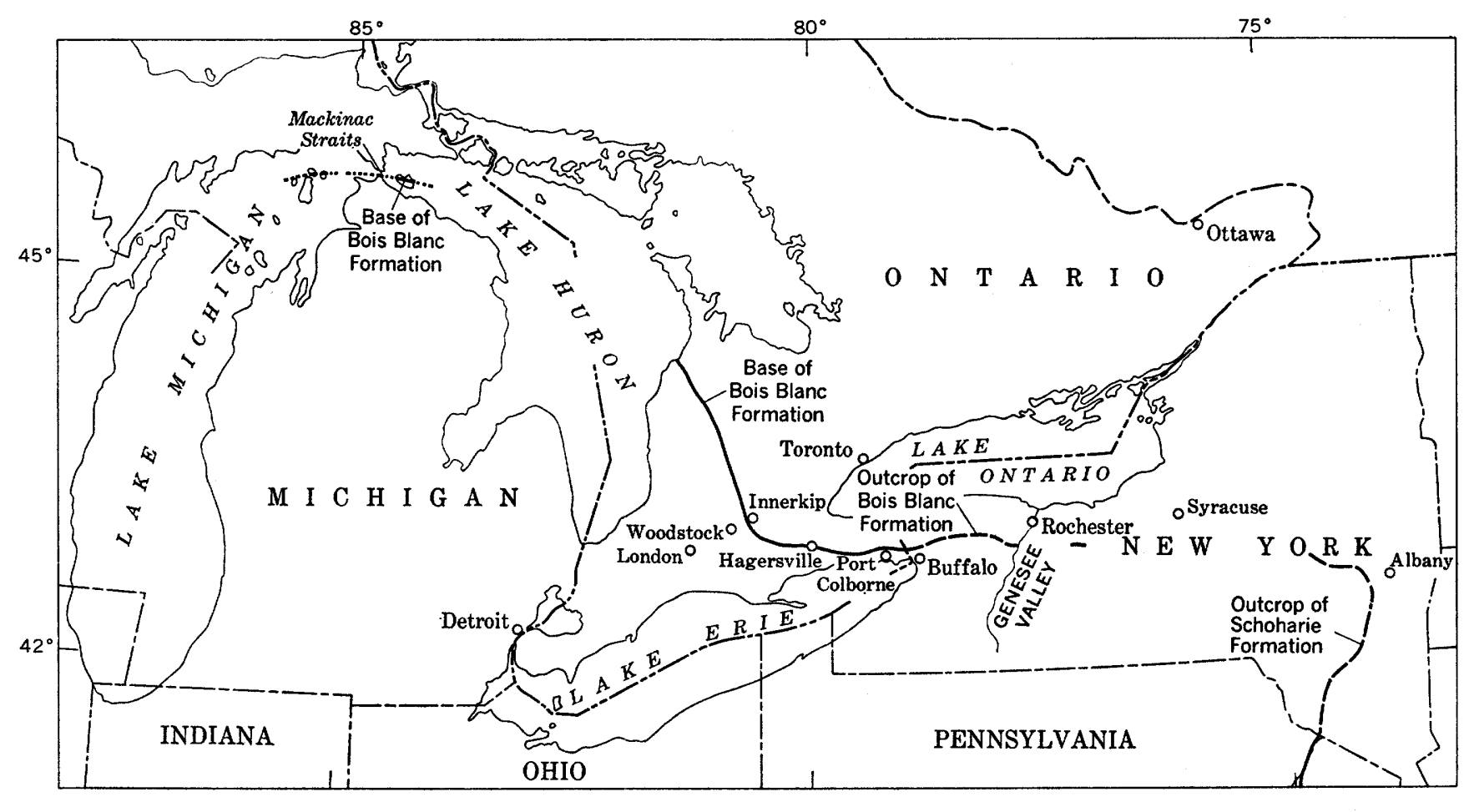

D., 100

Frgure 2.-Index map of areas and localities in Michigan, southwestern Ontario, and New York. The outcrop patterns of the Bois Blanc Formation in western New York and the Schoharie Formation in eastern New York are indicated. The broken line suggests the discontinuous nature of the Bois Blane in western New York but is diagrammatic. In Ontario northwest of Hagarsville, and in northern Michigan, the Bois Blanc line represents the outerop of the base of the thickened formation.

3. Highly calcareous, semicrystalline, gray limestone in massive beds separated by greenish shale partings; corals and large crinoid stems abundant.

2. Argillaceous brownish limestone with fossils in semicrystalline streaks.

1. Compact, cherty gray limestone with brachiopods.

Unit 1 is the Bois Blanc Formation of this report. Unit 2 is only locally developed near Port Colborne but is mostly of Onondaga age. Units 3 to 5 are the characteristic sequence in the lower Onondaga and represent the Edgecliff Member and the lower part of the Clarence Member. In numerous sections described by Stauffer, the Bois Blanc can be recognized by its lithology or contained fossils. Stauffer (1915, p. 19-20) recognized the anomaly presented by the fauna of unit 1 . "As has been observed this fauna is markedly different from that of the usual outcrops of the Onondaga Limestone in Ontario. A few of its forms have not been found, while others are rare, at higher horizons $* * *$. It is distinctly the fauna of the lower 15 or 20 feet of the Onondaga Limestone."

Somewhat earlier, Stauffer $(1913$, p. 85$)$ had named a sandstone, at the base of his "Onondaga," the Springvale Sandstone and ended a long period during which this sandstone was termed "Oriskany" in spite of its distinctly "Onondaga" fauna. Stauffer referred to the "Onondaga" all that would now be termed "Bois Blanc," "Onondaga," and "Detroit River." His Springvale was a basal member of the "Onondaga formation."

Caley $(1940,1941,1943,1945)$ in a series of areal studies in southwestern Ontario used the name "Onondaga" for the Devonian limestones in the Niagara Peninsula and thus followed Stauffer and other earlier workers. However, for the more involved sequence farther west in Ontario (now Bois Blanc, Detroit River, "Columbus," and Delaware) he (1941, p. 49) introduced the term "Norfolk Formation." (See fig. 1.) This name served an interim function but has not been used by subsequent workers who recognized the subdivisions and their stratigraphic relationships to surrounding areas.

Cooper (in Cooper and others, 1942, p. 1774) was referring to the beds classed here as Bois Blanc when he stated that a "lower Onondaga" fauna "having many Schoharie and Camden elements and characterized by Amphigenia and many corals is best developed west of New York in the southern peninsula of Ontario." No localities were indicated but this represents the first 
clear recognition of the Schoharie (=Bois Blanc) fauna in western New York or the Niagara Peninsula of Ontario.

Flower (1943) referred to the presence in western New York and Ontario of a "lower Onondaga" fauna containing fossils reminiscent of the Schoharie.

Ehlers (1945, p. 34, 80-109) named the Bois Blanc Formation for rocks in the Mackinac Straits region, Michigan (fig. 2). He related the lower and middle parts of his formation to Cooper's "lower Onondaga" fauna with Schoharie elements but left the upper Bois Blanc as "Onondaga" in a more general sense. Ehlers also noted (p. 107-108) that A. W. Grabau had recognized the Schoharie fauna in the Michigan rocks as early as 1906. No more definitive study of the type Bois Blanc Formation has been made since Ehlers' work, and the age of the upper part remains in question. All published evidence, however, points to the existence at the top of the Bois Blanc in Michigan of the same faunal break that is recognized in Ontario and New York. Ehlers' sequence of carbonate formations-Bois Blanc, Detroit River, and Dundee-had a marked effect on subsequent work in southwestern Ontario.

Caley (1947); Ehlers and Stumm (1951); Ehlers, Stumm and Kesling (1951); Stumm, Kellum, and Wright (1956) ; and Stauffer (1957) correlated all or part of the New York Onondaga with the Michigan Basin Bois Blanc. These authors extended the work of Ehlers (1945) to Ontario and recognized the Woodstock area sequence of Bois Blanc or "Onondaga," Detroit River, "Columbus," and Delaware or Dundee (fig. 1).

Ehlers, Stumm, and Kesling (1951) presented the correlations shown in figure 3. The "Amphigenia Zone" was not defined and could be interpreted in two ways. If the zone of small Amphigenia (fig. 4) was meant,

\begin{tabular}{|c|c|c|}
\hline Northern Michigan & & New York \\
\hline Dundee & & Marcellus \\
\hline 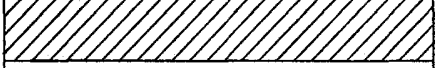 & \multirow{3}{*}{$\begin{array}{l}\mathbb{8} \\
00 \\
\mathbb{8} \\
\overline{0} \\
0 \\
0\end{array}$} & Paraspirifer Zone \\
\hline Detroit River & & Ell1111111111 \\
\hline Bois Blanc & & Amphigenia Zone \\
\hline
\end{tabular}

FIGURE 3.-Onondaga-Detroit River correlations according to Ehlers, Stumm, and Kesling (1951, chart 2).

FIGURE 4.-Composite columnar section of the Bois Blanc and Onondaga Formations in western New York based on exposures near Buffalo. The known ranges in western New York of large and small varieties of Amphigenia elongata are shown. The range of Paraspirifer acuminatus overlaps that of $A m p h i g e n i a$ elongata as indicated.

\section{BOIS BLANC FORMATION IN NEW YORK}

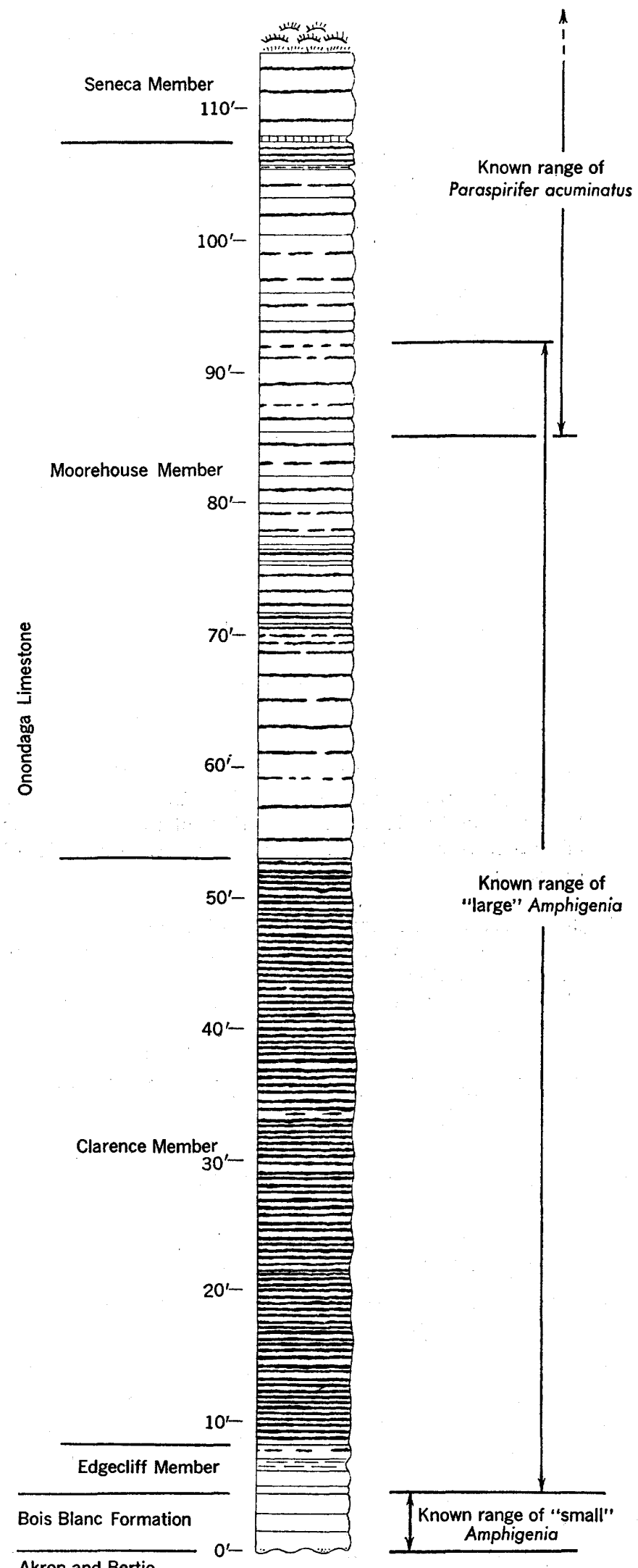


the scheme left the lower half of the Onondaga unaccounted for. If the total observed range of Amphigenia was meant (fig. 4), then most of the "Amphigenia Zone" is post-Bois Blanc in age. The evidence presented in this report indicates that only the zone of small Amphigenia can be correlated with the Schoharie and Bois Blanc. In addition there is much evidence to indicate that the Detroit River is a facies of the Onondaga and that both the New York and Michigan sequences are more complete than indicated by Ehlers, Stumm, and Kesling.

Sanford and Brady (1955, p. 6) extended usage of the name Bois Blanc into Ontario for the unit west of the Findlay arch where the unit underlies the Detroit River Group or Formation.

Although the earlier work of Stauffer (1915) and Cooper and others (1942) in correlating the Ontario sequence with the New York standard section had a New York orientation, the subsequent work of Ehlers (1945) through that of Stauffer (1957) was oriented toward the Michigan Basin. This later work succeeded in establishing the correct sequence of formations in central southwestern Ontario but extrapolations eastward to New York failed because of a lack of detailed information on the Niagara Peninsula and New York stratigraphy.

Oliver $(1954,1956)$ began to fill this gap by redescribing the Onondaga Limestone in New York. The zone of small Amphigenia was described as Zone B of the Onondaga and the Zone B fauna was compared with that of Stauffer's (1915) lower brachiopod beds from just west of the Niagara River in Ontario. No attempt was made to correlate the New York section with the Michigan Basin section.

Caley and Liberty (1957, p. 225-226) briefly summarized the Ontario succession once more and correlated the Bois Blanc with the "lower Onondaga of New York," the Detroit River with the "middle Onondaga," and the "Columbus" with the "upper Onondaga." This represented a significant advance over the suggestions of Ehlers, Stumm, and Kesling (1951) shown in figure 3 , but no attempt was made to define lower, middle, and upper Onondaga.

On the geological map of southwestern Ontario (Canada Geological Survey, 1958) the Bois Blanc map unit included Onondaga as well as Bois Blanc in the Niagara Peninsula. This map may have been completed earlier than the summary by Caley and Liberty (1957) noted previously, and presumably the authors of the map would no longer consider the Niagara Peninsula formations to be entirely pre-Detroit River in age.

Oliver (1958, p. 829-837) described the coral Aemulophyllum exiguum (Billings) from eastern and western New York and the Niagara Peninsula of Ontario. The specimens are from the Bois Blanc and Schoharie Formations although this was not understood at the time.

Oliver (1960) correlated the western New York zone of small Amphigenia with the Bois Blanc and excluded it from the Onondaga. He stated that "the pre-Edgecliff Amphigenia zone in western New York and adjacent Ontario can be considered as the eastern feather edge of the Bois Blanc Formation" and suggested that the Bois Blanc (Amphigenia zone) may be separated from the overlying Detroit River and Onondaga by an unconformity. This work was based on a study of the coral faunas.

Boucot $(1959,1960,1962$, and numerous oral communications) described and discussed brachiopod faunas of Schoharie age from eastern New York, New England, and the Maritime Provinces (Canada). Unfortunately, no comparable studies of Onondaga age brachiopods have been made. Boucot (1959) used "lower Onondaga" to mean Schoharie in the earlier sense of Cooper and others (1942), but he later referred to "Zone B" or Schoharie. The most complete summaries of the brachiopod work to date are those of Amsden (1963, p. 150-162) and Boucot and Johnson (1968). Paleogeographic implications of the Schoharie brachiopod fauna were summarized by Boucot and Johnson (1964, 1968).

Over the years covered by this summary, the rocks here termed Bois Blanc, Schoharie, and Onondaga in New York and the Niagara Peninsula of Ontario have been dated as Early Devonian, Early or Middle Devonian, or Middle Devonian by the various workers. By and large the coral specialists (G. M. Ehlers, E. C. Stumm, and W. A. Oliver, Jr.) have favored Middle Devonian, whereas the brachiopod specialists (G. A. Cooper, A. J. Boucot, and others) have consistently favored Early Devonian. The evidence reviewed and summarized by Boucot and Johnson (1968) clearly indicates a late Early Devonian age for the Bois Blanc, Schoharie, and equivalents. Evidence for a Middle Devonian age for the overlying Onondaga was summarized by Oliver $(1960,1966)$.

\section{DESCRIPTIVE STRATIGRAPHY}

The Bois Blanc Formation in western New York and the Niagara Peninsula of Ontario is a medium-darkgray, fine-grained limestone with a fauna numerically dominated by brachiopods although containing many corals. Chert is uncommon in New York but becomes common west of the Niagara River where sections are thicker. The thickness in New York varies irregularly from a few inches to four feet, but the formation is discontinuous and is absent in many places. Only one exposure is known east of the Genesee Valley (fig. 2). 
West of Buffalo the formation thickens to approximately 15 feet at Port Colborne and to at least 24 feet at Hagarsville. It is probably laterally continuous west of Port Colborne and for some distance east, but outcrops are too few for more detailed mapping in this area. Where the Bois Blanc is present, its lithology is in strong contrast to the overlying coarse crinoidal, coralline limestone that forms the lowest member of the Onondaga.

Fossils are abundant in the Bois Blanc. Brachiopods, corals, gastropods, and trilobites are most common. Key forms for field recognition of the Schoharie-Bois Blanc fauna in eastern North America including the area under discussion are the corals Aemulophyllum exigunm (Billings) and Acrophyllum oneidaense (Billings). Both these species have distinctive features easily recognized in the field from either broken or complete specimens. Among the brachipods, Acrospirifer duodenaria (Hall), Coelospira camilla (Hall), Centronella glansfagea (Hall), and small specimens of Amphigenia elongata (Vanuxem) are common and usually recognizable. Large specimens of Amphigenia elongata range through the lower three members of the Onondaga in New York (fig. 4) but are not common. In western New York and the Niagara Peninsula of Ontario, the presence of the key corals and (or) the profusion of brachiopods is sufficient to separate the Bois Blane from the coral-crinoid debris assemblage of the overlying Edgecliff Member of the Onondaga.

The Bois Blanc disconformably overlies the Oriskany Sandstone in one or more small areas in the Niagara Peninsula. Elsewhere, it rests on Silurian rocks of the Akron and Bertie Formations (fig. 1). At many outcrops the lower part of the formation includes sand grains of Oriskany type and presumably derived by the reworking of Oriskany deposits in the early Bois Blanc sea. Locally the sand forms a sandstone bed 8 or 10 feet thick, as is found around Springvale and Hagarsville, Ontario (Stauffer, 1915, p. 7). More commonly the sand bed is only a few inches thick or consists of sand grains scattered through the lower few inches of the limestone. This sandstone was termed the Springvale Member by Stauffer (1913, p. 85; 1915, p. 7, 77-87). The Springvale Member contains Bois Blanc fossils and the name serves to distinguish the sandstone of Bois Blanc age from the true Oriskany. Sand is not everywhere present at the base of the Bois Blanc, and no real sandstone bed of any thickness is known in the New York outcrops of the formation. Use of the name Springvale Member should be restricted to Ontario because it is so weakly developed in New York and has been confused with sandstone beds of similar origin at the base of the Onondaga Formation.
The upper contact of the Bois Blanc is marked by an abrupt lithologic and faunal change as has been stated previously. This suggests that the contact might be disconformable (Oliver, 1960, p. 173). Additional physical evidence for this is found in the distribution of sand in the base of the Onondaga. The basal sand of the Onondaga is similar to the sand in the Bois Blanc, and the presence of sand at the base of the limestone sequence in both Ontario and central New York has certainly influenced usage of the term "Onondaga" in Ontario. Commonly the sand, if present, is found at the base of whichever formation rests on the Oriskany or on older rocks beneath the post-Oriskany unconformity. Locally, however, the sand is present in the basal Onondaga, even where it overlies the Bois Blanc Formation. In many areas pre-Onondaga erosion apparently removed the Bois Blanc and reworked sand from either the Bois Blanc or the Oriskany into the lowest Onondaga deposits. Locally, the Onondaga sea washed the sand over Bois Blanc remnants where it was incorporated into the basal Onondaga. Given the situation where sand may be present or absent in the base of either formation and the lower formation is discontinuous, six possible sequences can exist. These are shown diagrammatically in figure 5. All the situations except sequence 4 are known to exist in western New York.

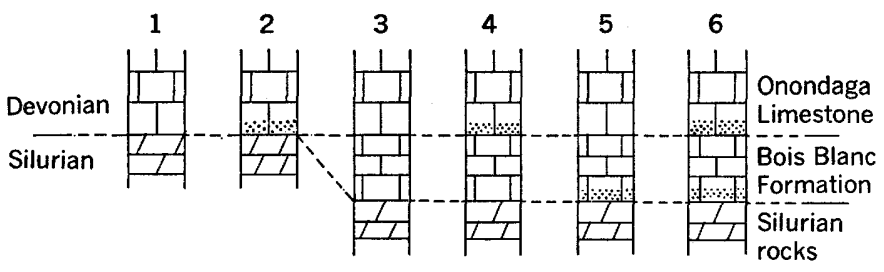

FIGURE 5.-Hypothetical basal Devonian sequences. Given two formations, the lower discontinuous and each with or without basal sand, these six sequences could exist. All but sequence 4 have been observed in western New York. The existence of sequence 6 is taken as physical evidence of a disconformity separating the Bois Blanc and Onondaga. Limestone, sandy limestone, and dolomite are represented by the conventional symbols.

The name Springvale Sandstone Member was proposed for use in Ontario, but Chadwick (1919, p. 42) and Oliver $(1954,1963)$ applied the name Springvale to well-developed sandstones in central New York that are basal Onondaga rather than Bois Blanc. This usage resulted from a misunderstanding of the detailed relationships of the stratigraphic units concerned and the name should be abandoned entirely in New York.

\section{LOCALITIES}

All localities at which the Bois Blanc Formation was studied are shown on plate 1. Fieldwork in New York 
was fairly detailed although more exposures could certainly be found. Localities where the Bois Blanc is definitely absent are also indicated and the discontinuous nature of the formation in New York is apparent.

Fieldwork in Ontario was much less thorough. An attempt was made to examine several outcrops between the Niagara River and Port Colborne and detailed studies and collections were made at Port Colborne and at Hagarsville.

In New York, abundant, well-silicified fossils were found only at locality 4672 . Additional silicified material was collected at four other localities. Descriptions of brachiopods (Boucot and Johnson, 1968) are based on etched specimens selected by Boucot from the New York collections listed here. Some localities have more than one number because of repeated visits in different years.

All locality numbers are from the Silurian-Devonian catalog of the U.S. Geological Survey. For full designation each number should be preceded by USGS and followed by -SD.

4671. Abandoned quarry just northeast of the intersection of Transit Road (N.Y. 78) and Sheridan Drive (N.Y. 324), Lancaster 71/2-minute quadrangle (Depew 15-minute quadrangle).

4672. Roadcuts on Goodrich Road, 0.8 mile north of Main Street (N.Y. 5), Lancaster 71/2-minute quadrangle (Depew 15-minute quadrangle).

5073. Same as 4671 .

5074. North side of New York Thruway at mile $334.05(0.35$ mile east of Everson Road), Phelps 71/2-minute quadrangle (east of area covered by plate 1 ; see fig. 2 ).

5075. Same as 5074 .

5335. Same as 4672 .

6095. Same as 4672 .

7535. Black Creek in Morganville, just south of bridge on N.Y. 237, Byron 71/2-minute quadrangle (Albion 15-minute quadrangle).

7536. Quarry, 2.6 miles east of Oatka Creek in Leroy and 1.2 miles north of N.Y. 5, Leroy 71/2-minute quadrangle (Caledonia 15-minute quadrangle).

7660. Crest of Buttermilk Falls of Oatka Creek, Churchville 71/2-minute quadrangle (Bergen 15-minute quadrangle).

\section{REFERENCES CITED}

Amsden, T. W., 1963, Articulate brachiopods of the Sallisaw Formation (Devonian) : Oklahoma Geol. Survey, Bull. 94, p. 141-192.

Boucot, A. J., 1959, Brachiopods of the Lower Devonian rocks at Highland Mills, New York: Jour. Paleontology, v. 33, no. 5, p. 727-769.

1960, Implications of Rhenish Lower Devonian brachiopods from Nova Scotia : Internat. Geol. Cong., 21st, Copenhagen, 1960, Rept., pt. 12, p. 129-137.

1962, Appalachian Siluro-Devonian, in Some aspects of the Variscan Fold Belt: Manchester, England, Manchester Univ. Press, p. 155-163.
Boucot, A. J., and Johnson, J. G., 1964, Devonian brachiopods from the Mina Plomosas-Placer de Guadalupe area, Chihuahua, Mexico, and their paleogeographic significance, in Geology of Mina Plomosas-Placer de Guadalupe area, Chihuahua, Mexico-Field trip guidebook, 1964: West Texas Geol. Soc. Pub. 64-50, p. 104-408.

1968, Brachiopods of the Bois Blanc Formation in New York: U.S. Geol. Survey Prof. Paper 584-B (in press).

Caley, J. F., 1940, Palaeozoic geology of the Toronto-Hamilton area, Ontario: Canada Geol. Survey Mem. 224, 284 p.

- 1941, Palaeozoic geology of the Brantford area, Ontario : Canada Geol. Survey Mem. 226, 176 p.

1943, Palaeozoic geology of the London area, Ontario: Canada Geol. Survey Mem. 237, 171 p.

1945, Palaeozoic geology of the Windsor-Sarnia area, Ontario: Canada Geol. Survey Mem. 240, 227 p.

1947, Stratigraphic position of the Detroit River Limestone in Ontario [abs.]: Geol. Soc. America Bull., v. 58, no. 12 , p. 1170 .

Caley, J. F., and Liberty, B. A., 1957, The St. Lawrence and Hudson Bay Lowlands, and Paleozoic outliers, Chapter 4 of Stockwell, C. H., ed., Geology and economic minerals of Canada: Canada Geol. Survey Econ. Geology Ser., no. 1, p. 207-246.

Canada Geological Survey, 1958, Geological map of southwestern Ontario showing oil and natural gas producing areas: Canada Geol. Survey Map 1062A, scale 1: 380,160.

Chadwick, G. H., 1919, Phelps quadrangle : New York State Mus. Bull. 207-208, p. 42-43.

- 1944, Silurian and Devonian geology, Part 2 of Geology of the Catskill and Kaaterskill quadrangles: New York State Mus. Bull. 336, 251 p.

Clarke, J. M., 1902, The indigene and alien faunas of the New York Devonic: New York State Mus. Bull. 52, p. 664-672.

Cooper, G. A., and others, 1942, Correlation of the Devonian sedimentary formations of North America : Geol. Soc. America Bull., v. 53, no. 12, pt. 1, p. 1729-1794.

Eardley, A. J., 1951, Structural geology of North America: New York, Harper \& Bros., $624 \mathrm{p}$.

Ehlers, G. M., 1945, Stratigraphy of the surface formations of the Mackinac Straits region, in Landes, K. K., Ehlers, G. M., and Stanley, G. M., Geology of the Mackinac Straits region and subsurface geology of northern Southern Peninsula: Michigan Geol. Survey Div., Pub. 44, p. 19-120.

Ehlers, G. M., and Stumm, E. C., 1951, Middle Devonian Columbus Limestone near Ingersoll, Ontario, Canada: Am. Assoc. Petroleum Geologists Bull., v. 35, no. 8, p. 1879-1888.

Ehlers, G. M., Stumm, E. C., and Kesling, R. V., 1951, Devonian rocks of southeastern Michigan and northwestern Ohio : Ann Arbor, Edwards Bros., $40 \mathrm{p}$.

Flower, R. H., 1943, Middle Devonian nautiloids of New York [abs.] : Geol. Soc. America Bull., v. 54, no. 12, p. 1830.

Goldring, Winifred, 1931, Handbook of paleontology for beginners and amateurs, Part 2, The formations: New York State Mus. Handb. 10, 488 p.

1935, Geology of the Berne quadrangle: New York State Mus. Bull. 303, 238 p.

1943, Geology of the Coxsackie quadrangle, New York: New York State Mus. Bull. 332, 374 p.

Goldring, Winifred, and Flower, R. H., 1942, Restudy of the Schoharie and Esopus Formations in New York State: Am. Jour. Sci., v. 240, no. 10, p. 673-694. 
Johnsen, J. H., and Southard, J. B., 1962, The Schoharie Formation in southeastern New York, in New York State Geological Association Guidebook, 34th annual meeting, Port Jervis, 1962 : p. A7-A15.

Oliver, W. A., Jr., 1954, Stratigraphy of the Onondaga Limestone (Devonian) in central New York: Geol. Soc. America Bull., v. 65, no. 7, p. 621-652.

1956, Stratigraphy of the Onondaga Limestone in eastern New York: Geol. Soc. America Bull., v. 67, no. 11, p. 14411474.

1958, Significance of external form in some Onondagan rugose corals: Jour. Paleontology, v. 32, no. 5, p. 815-837, pls. 104-106.

1960, Coral faunas in the Onondaga Limestone of New York: U.S. Geol. Survey Prof. Paper 400-B, p. 172-174.

1963, The Onondaga Limestone, in Stratigraphy, facies, changes and paleoecology of the Lower Devonian Helderberg limestones and Middle Devonian Onondaga Limestones, in Geological Society of America Guidebook, 76th annual meeting, Field trip No. 1, Mohawk and Central Hudson Valley, New York, 1963: p. 11-16, 20-21, 26-27, 29-33.

1966, The Bois Blanc and Onondaga Formations in west- ern New York and adjacent Ontario, in New York State Geological Association Guidebook, 38th annual meeting, Buffalo, 1966 : p. 32-43.

Rickard, L. V., 1964, Correlation of the Devonian rocks in New York State: New York State Mus. and Sci. Service, Geol. Survey Map and Chart Ser., no. 4.

Ruedemann, Rudolf, 1930, Geology of the capital district: New York State Mus. Bull. 285, 218 p.

Sanford, B. V., and Brady, W. B., 1955, Palaeozoic geology of the Windsor-Sarnia area, Ontario: Canada Geol. Survey Mem. $278,65 \mathrm{p}$.

Stauffer, C. R., 1913, Geology of the region around Hagarsville [Ontario] : Internat. Geol. Cong., 12th., Toronto 1913, Guidebook 4, p. 82-99.

1915, The Devonian of southwestern Ontario: Canada, Geol. Survey Mem. 34, 341 p.

1957, The Columbus Limestone: Jour. Geology, v. 65, no. 4, p. 376-383.

Stumm, E. C., Kellum, L. B., and Wright, J. D., 1956, The Devonian strata of the London-Sarnia area, southwestern Ontario, Canada, in Michigan Geological Society Guidebook, ann. field trip, 1956: $21 \mathrm{p}$. 